128-1 | 2016

Sources et approches des biographies cardinalices $\left(\mathrm{XIX} \mathrm{X}^{\mathrm{e}} \mathrm{XX} \mathrm{X}^{\mathrm{e}} \mathrm{s}\right.$.) - Familles laborieuses. Rémunération, transmission et apprentissage dans les ateliers familiaux de la fin du Moyen Âge à l'époque contemporaine en Europe - Varia

\title{
The price of an apprentice : contracts and trials in the woollen industry in sixteenth century Italy
}

\author{
Andrea Caracausi
}

\section{revues.org}

Electronic version

URL: http://mefrim.revues.org/2476

DOI: $10.4000 /$ mefrim. 2476

ISSN: $1724-2142$
Publisher

École française de Rome

Printed version

ISBN: 978-2-7283-1190-3

ISSN: 1123-9891

Brought to you by Aix-Marseille Université (AMU)

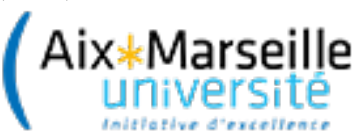

Electronic reference

Andrea Caracausi, «The price of an apprentice : contracts and trials in the woollen industry in sixteenth century Italy ", Mélanges de l'École française de Rome - Italie et Méditerranée modernes et contemporaines [Online], 128-1 | 2016, Online since 03 March 2016, connection on 02 December 2017. URL : http://mefrim.revues.org/2476 ; DOI : 10.4000/mefrim.2476 


\title{
The price of an apprentice
}

\section{Contracts and trials in the woollen industry in $16^{\text {th }}$ century Italy}

\author{
Andrea CARACAUSi
}

A. Caracausi, Department of Historical and Geographic Sciences and the Ancient World, University of Padua, andrea.caracausi@unipd.it

\begin{abstract}
The history of work in the modern era has - often unfairly - considered children's work to be a minor aspect of the household, if not "complementary» to the economic activities unfolding within it. While the traditional garzonato [apprenticeship] represented a formative stage of an adolescent's life, geared toward learning a trade that would be practiced in adulthood, other work done outside of a trade career was considered - often incorrectly - as "minor" and as a mere response to a family's economic or structural difficulties. As a result the wages of pueri, that is children between the ages of 7 and 14, were usually considered "supplementary" to the household budget in relation to the wages of more adult workers, and thus stripped of their individual nature. However, research on certain Italian and European cities has enabled a partial revision of these interpretations, offering a broader framework for the causes and significance of children's work in modern times. Drawing on the proceedings from a number of central and northern Italian civil and business courts (Padua, Florence, Vicenza, Milan), cross-checked with a large body of notarial acts, this paper seeks to show how children's wages played a role that went beyond just remunerating work or supplementing family income. In fact, wages were primarily a means to ensure the temporal continuity of a relationship of debt and credit between two or more people, allowing the children - and their respective parents and guardians - to enter into relationships with other individuals and build social as well as economic ties that might prove useful in the future. Second, children's wages were not set according to a 'standard', but rather reflected apprentices' individual characteristics, which were primarily defined by the characteristics of their biological family. Finally, by earning wages these children were able to begin a long process of integration into ancien régime society. On the basis of these and other elements this paper proposes to critically discuss the nature, role and function of children's wages in modern times.
\end{abstract}

Apprenticeship, children's work, salaries, contracts

\section{INTRODUCTION}

Over recent decades, studies in the social and economic history of pre-modern Europe have analysed the role of apprenticeship in manufacturing activities in some depth. The focus has been normally on how such contracts and related institutions (especially craft guilds) transmitted technical knowledge from generation to generation reducing opportunistic behaviour and adverse selection between trainers and trainees ${ }^{1}$. Further

1. This research was carried out within the framework of the FIRB 2012 Research Project RBFR12GBQZ_002. I would like to thank Sheilagh Ogilvie and Francesco Vianello for their stimulating comments on earlier version of this paper, and Raffaella Sarti on the final text. On apprenticeship and human capital see Gustafsson 1991, p. 21; research has highlighted the ways in which apprenticeship served to socialize young boys and girls into the world as the first step in their pre-adulthood life cycles ${ }^{2}$.

Whilst such studies are important, the wage-formation and contract negotiation mechanisms used by masters and apprentices have been analysed to a much lesser extent ${ }^{3}$. These aspects

Epstein 1998, p. 688-93; Lucassen et al. 2008, p. 14, 17; Epstein and Prak 2008, p. 7-11; Epstein 2008, p. 56-63; Pfister 2008, p. 26-27; Van Zanden 2009, p. 160-76; Wallis 2008, p. 854; Minns - Wallis 2012, p. 552, 574; Minns Wallis 2013, p. 349. See however, Ogilvie 2004, p. 303-14; Ogilvie 2008, p. 177-78; Ogilvie 2014, p. 183-184.

2. De Munck et al. 2007, p. 10; Ben Amos 1988; Ben Amos 1991; Bellavitis 2006; Laudani 2006.

3. On this point see Martini - Bellavitis 2014. 
The price of an apprentice : contracts and trials in the woollen industry in $16^{\text {th }}$ century Italy

146 Andrea Caracausi

played a central role in the functioning and understanding of pre-modern apprenticeship nonetheless. On one hand, such analysis gives us an understanding of the factors involved in estimating the worth of an apprentice. On the other, it gives us an insight into whether apprenticeship contracts were really the necessary tool in limiting adverse selection and opportunistic behaviours claimed in the literature.

This article aims to investigate the ways in which masters and apprentices entered contracts, highlighting elements in apprentice wage calculations, the mechanisms used to work these out and pre-contract signing procedures. To this end, I will focus on sixteenth century Italy combining apprenticeship contracts and court cases from the woollen guild courts of Padua and Florence. The woollen industry is a useful case study in apprentice wage-formation analysis and the two cities represent this branch of industry well. Padua was a medium-sized city $(25,000-30,000$ inhabitants) and its wool industry was relatively stable during the sixteenth century (about 1500-2000 cloths a year). Florence was larger (about 60,000-70,000 inhabitants) and its wool production peaked in the mid-sixteenth century (16-18,000 cloths a year) but declined gradually from the 1580s onwards. The labour market was characterised by a range of labour relations and considerable workforce heterogeneity whilst the technology used required both skilled workers for high-quality woollen cloth and bonnet making and unskilled workers for medium and low-quality items ${ }^{4}$.

From an institutional point of view, two «sectoral» guilds managed the sector. Whereas board council members were exclusively cloth manufacturers, the guild courts were open to everyone who worked in the trade whatever their age, gender or status ${ }^{5}$. Masters and apprentices could appeal to guild judges on opportunistic behaviour, contract renegotiation and debt refunding issues. Both courts had criminal and civil roles, used inquisitorial systems and could imprison and torture suspects. In Padua one of the three judges had to have at least five years of expe-

4. Chorley 2003; Ammannati 2008; Ammannati 2009; Maitte 2001; Panciera 1996; Caracausi 2008.

5. Ammannati 2014, p. 60; Caracausi 2008. For a definition of 'sectoral' guild see Pfister 2008. rience as a jurist while in Florence the five wool guild judges were all merchants ${ }^{6}$.

A combined analysis of apprenticeship contracts and court cases is particularly useful for an analysis of wage-formation and contract negotiation mechanisms. On one hand, formal agreements drawn up from notarial records or guild books can be used as the basis for wage calculations made according to length of contract and contractual obligations. On the other, court cases shed light on practices related to drawing up or terminating contracts ${ }^{7}$. The main results of these two case studies will provide insights for future research work in other pre-industrial sectors.

The next section analyses apprenticeship contracts and wage-levels showing the extent to which contract length and duties affected actual wage levels. The third section discusses the elements that explain this variability and the way they contributed to employers' wage estimates. My fourth section discusses the mechanisms used to recruit apprentices, especially that designed to reduce information asymmetries before contracts were signed. The final section outlines some general implications for a historical analysis of master-apprentice relationships.

\section{CONTRACTS, APPRENTICES AND WAGES}

In common with many other Italian textile cities $^{8}$, no compulsory apprenticeship terms were fixed in the various stages of the woollen production chain (beating, combing, knitting, fulling, weaving, scouring, shearing, napping and raising) in Padua and Florence. Master craftsmen took no examination or test but simply paid a registration fee 9 . In Padua, minimum apprenticeship terms and membership examinations were introduced for cloth and knitted cloth manufacturers only

6. Franceschi 1993; Caracausi 2008.

7. See Archivio di Stato di Padova [hereafter ASP], Università della lana [hereafter UL], 48-70, 77-88; Archivio di Stato di Firenze [hereafter ASF], Arte della Lana [AL], 285, 288, 295, 296, 297, 300, 303, 305, 347-8, 368, 370-8, 381, 384-5.

8. Only around $40 \%$ of Italian guild ordinances contained apprenticeship regulations: see Mocarelli 2008, p. 171. For non-guilded woolen industries across Europe see Ogilvie 2014, p. 182-183.

9. Ammannati 2014, p. 73; Caracausi 2008. 
later, in the $1630 \mathrm{~s}^{10}$. Although the two guilds did not impose compulsory apprenticeship periods, however, many private and oral contracts did regulate master-apprentice relationships nonetheless ${ }^{11}$.

In Padua and Florence, written apprenticeship agreements were signed in the notary's office, privately, or before guild officials. They normally included five key points: the names of those signing the contract, the length of the contract, the craft to be learned (including other duties), type of remuneration (in kind, money or mixed) and the timing of payment. In general, remuneration included an apprentice's money, food and lodging ${ }^{12}$. Unfortunately, apprentice age is often missing from such documents making quantitative investigation on this very important element impossible.

For quantitative purposes I have analysed 130 Florentine apprenticeship contracts in various manufacturing stages of the wool art for the 1560-73 period. Contracts were most frequently drawn up for weaving and wool preparation (especially wool beating) apprenticeships which accounted for $78(60 \%)$ and $39(30 \%)$, respectively, of the 130 total contracts. As Tab. 1 shows, apprenticeship contracts (drawn up explicitly "in order to learn the craft of ...") varied significantly in length, ranging from 6 to 60 months for wool preparers and 12 to 96 months for weavers. The second point is that contract time frames were not always whole years ( $1,2,3$ years) but sometimes also months. Nevertheless, in the weaving trade contracts most commonly lasted three (10 contracts, $13 \%$ of total contracts for weaving), four $(14,28 \%)$ or six years $(13,17 \%)$, whilst for wool preparation they generally lasted one $(7,18 \%)$ or three years $(10,26 \%)$. However, in both crafts contracts were also signed for a total of 14, 15, 42 or 86 months. This variation alone raises a number of questions on how the time frames required to learn a craft and the wages an apprentice deserved were worked out. However, before I look at the relationship between length of contract and wages, it would also be interesting to examine the way contract length varied according to an apprentice's gender. In general, there were fewer female than male contracts in beating and weaving and they were generally longer term (48 months for men, 72 for women).

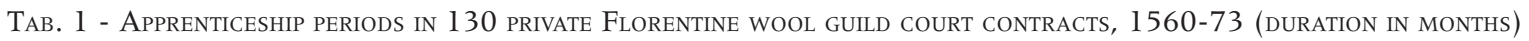

\begin{tabular}{|c|c|c|c|c|c|c|c|c|c|c|c|c|c|c|c|c|c|c|c|c|}
\hline \multirow[b]{2}{*}{ Crafts } & \multicolumn{20}{|c|}{ Months } \\
\hline & 6 & 8 & 12 & 14 & 15 & 16 & 18 & 24 & 30 & 36 & 42 & 48 & 54 & 60 & 66 & 72 & 84 & 96 & 120 & $\begin{array}{l}\text { No. of } \\
\text { Contracts }\end{array}$ \\
\hline Knitters & & & & & & & & & & 2 & & & & & & & & & & 2 \\
\hline $\begin{array}{l}\text { Wool- } \\
\text { preparers }\end{array}$ & 1 & 1 & 7 & & & & 3 & 6 & & 10 & 1 & 6 & & 4 & & & & & & 39 \\
\hline $\begin{array}{l}\text { Bonnet- } \\
\text { makers }\end{array}$ & & & & & & & & & & 6 & & & & & & & & & 1 & 7 \\
\hline $\begin{array}{l}\text { Napping- } \\
\text { Raising }\end{array}$ & & & 1 & & & & & 2 & & & & & & & & & & & & 3 \\
\hline $\begin{array}{l}\text { Warp- } \\
\text { makers }\end{array}$ & & & & & & & & & & 1 & & & & & & & & & & 1 \\
\hline Weavers & & & 4 & 1 & 1 & 1 & 3 & 7 & 4 & 10 & 3 & 11 & 3 & 8 & 1 & 13 & 4 & 4 & & 78 \\
\hline $\begin{array}{l}\text { No. of } \\
\text { contracts }\end{array}$ & 1 & 1 & 12 & 1 & 1 & 1 & 6 & 15 & 4 & 29 & 4 & 17 & 3 & 12 & 1 & 13 & 4 & 4 & 1 & 130 \\
\hline
\end{tabular}

Sources: ASF, AL, 287-8, 300, 303, 295

10. And a dyer's guild was set up only in the 1670s with a minimum apprenticeship term requirement. However apprenticeship was set up for fiscal rather than training purposes. I discussed the foundation of the dyer's guild in Caracausi 2014.

11. Caracausi 2008; Caracausi 2014; Ammannati 2008; Ammannati 2014, p. 72.

12. For references, see Carmona 1964; Malanima 1982; Marcello 1993; Caracausi 2008, 2010. 
The price of an apprentice : contracts and trials in the woollen industry in $16^{\text {th }}$ century Italy

148 Andrea Caracausi

TAB. 2. Length of APPRENTiCeship by GENDER IN 130 PRIVATE CONTRACTS SIGNED IN THe FlorenCe WOOLLEN COURT (1560-1573)

\begin{tabular}{|l|l|l|l|l|l|l|l|l|l|l|l|l|l|l|l|l|l|l|l|}
\hline Months & 6 & 8 & 12 & 14 & 15 & 16 & 18 & 24 & 30 & 36 & 42 & 48 & 54 & 60 & 66 & 72 & 84 & 96 & Contracts \\
\hline Crafts & & & & & & & & 1 & & 2 & & & & & & & & & 3 \\
\hline $\begin{array}{l}\text { Female com- } \\
\text { bers }\end{array}$ \\
\hline $\begin{array}{l}\text { Male com- } \\
\text { bers }\end{array}$ & 1 & 1 & 7 & & & & 3 & 5 & & 8 & 1 & 6 & & 4 & & & & & 36 \\
\hline $\begin{array}{l}\text { Total combers } \\
\text { Female }\end{array}$ & 1 & 1 & 7 & & & & 3 & 6 & & 10 & 1 & 6 & & 4 & & & & & 39 \\
\hline $\begin{array}{l}\text { Meavers } \\
\text { Weavers }\end{array}$ & & & & & & & & 1 & & 1 & & 1 & & 2 & & 8 & 3 & 3 & 19 \\
\hline Total weavers & & & 4 & 1 & 1 & 1 & 3 & 7 & 4 & 10 & 3 & 11 & 3 & 8 & 1 & 13 & 4 & 4 & 78 \\
\hline Contracts & 1 & 1 & 11 & 1 & 1 & 1 & 6 & 13 & 4 & 20 & 4 & 17 & 3 & 12 & 1 & 13 & 4 & 4 & 117 \\
\hline
\end{tabular}

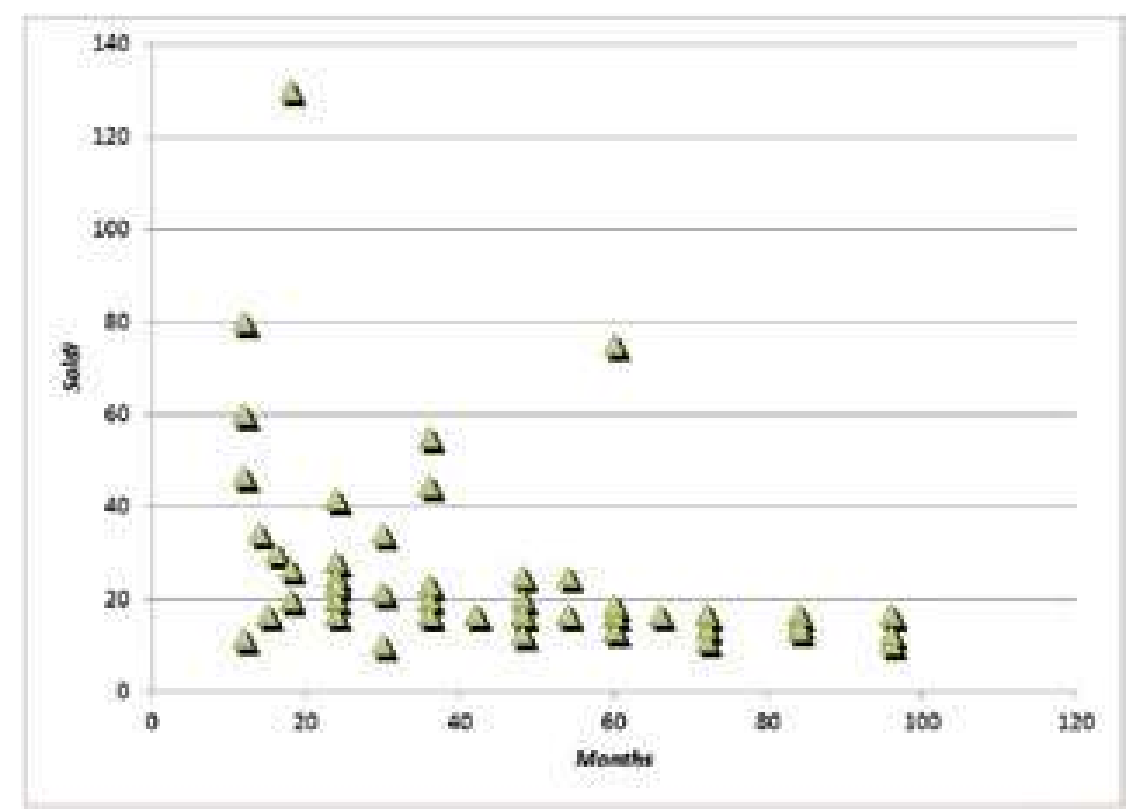

Fig. 1 - Monthly wages for apprentices in 78 Florentine wool guild court contracts, 1560-1573.

This quantitative analysis on contracts leads in to the wage-levels issue. Apprentices were normally paid a yearly salary. Generally, longer contracts did not pay a wage for the first year which can probably be explained by the fact that longer contracts were signed with younger apprentices who were probably less productive than older ones. In order to compare wage-levels, I have calculated them on a monthly basis. Comparing monthly wages with length of contract gives us the following wage-distribution (Fig. 1). I have analysed apprenticeship contracts for weaving alone, as there were more of these (78) than in other crafts.
Two main points emerge here. Firstly, wages varied according to length of contract. However, whereas longer periods corresponded to lower and more standardised wages, in shorter contracts there was greater wage dispersion and differentiation. The second element is that whereas wages converged around the figure of 10 lire per year (200 soldi, about 17 soldi a month) in 35 cases ( $45 \%$ on total contracts for the art of weaving), they could vary greatly even within the same time frame: from 12 to as much as 80 soldi monthly for a one year contract, from 17 to 42 soldi monthly for a two year contract, from 17 to 55 soldi monthly 
for a three year contract and from 13 to 75 soldi monthly for a five year contract. It is therefore necessary to analyse the reasons behind these variations and the elements that contributed to wage-formation.

\section{WAGE-FORMATION}

Why were there such differences in contract length and wage-levels? Which factors influenced wage-formation? Court cases can give us a better understanding of what apprenticeship contracts cannot tell us, especially given the absence of age and other information.

As I have already noted, the first variable accounting for wage-differentiation was length of the contract. This depended on the fact that in the high-quality wool industry it did not take very long to train an apprentice and time frames varied. Master weavers were clear about the fact that apprentices were capable of assisting other journeymen in cloth weaving in less than a year and that by the third year of his apprenticeship a 15-year-old boy was capable of working as a journeyman. Pasquino di Francesco from Romagna, a Florentine weaver, testified that after 12 months as an apprentice, Gerolamo was not capable of working as a journeyman, but he "had learned enough to be guided" and could weave with other journeymen ${ }^{13}$. On the other hand, weaver Jacopo, son of Tommaso from Pistoia argued that an apprentice like Domenico ( 15 years old) was capable of weaving one woollen cloth (rascia) per month in the latter two years of his contract as long as he worked with another apprentice. Masters, he went on, earned more by employing apprentices like him than other journeymen ${ }^{14}$.

The second element contributing to wage levels was an apprentice's aptitude. Court cases dealing with contract termination show this clearly. Damages demanded by masters depended on individual apprentices and their aptitude for work. Florentine weaver Evangelista calculated about 35 lire damages for 32 months for the early departure of young Elisabetta after ten months of appren-

13. ASF, AL, b. 372, trial no. 386, 30 Mar. 1569.

14. ASF, AL, 373, trial no. 236, 31 Mar. 1571. ticeship ${ }^{15}$. Battista, son of Andrea from Bologna, and Bartolo, son of Girolamo from Castiglione, estimated about 100 lire for 17-year-old Gerolamo ( "who was well learned in the art of weaving") who left his master during the third year of his contract ${ }^{16}$. Weavers Luigi, son of Antonio from Faenza, Marco, son of Gaspare da Montopoli, and Baldassarre, son of Antonio, evaluated the 24 months that a 15-year-old boy did not complete within a 5-year apprenticeship contract at 7, 8 or 10 lire per month ${ }^{17}$. Such sums were a very large amount to ask to parents (as we have seen, 10 lire was a boy's yearly salary on average) and went far beyond the costs that masters incurred in training apprentices.

Alongside age and aptitude, the third element contributing to wage levels was the amount of manual work and service that apprentices were required to do in addition to learning the craft. Apprentices performed manual labour either alongside masters or supervised by journeymen while masters or merchants did other work ${ }^{18}$. Duties varied according to occupation. Apprentices did not spend all their working hours at the loom, but their time was often spent carrying half-finished products to other workshops for external processing (fulling and dyeing), monitoring other workers in the shop and guarding the master's or merchant's house or various workshops ${ }^{19}$.

An apprentice's productivity was the fourth element contributing to wage differentiation. Florentine textile weavers believed that masters gained more from hiring 15-year-old "well learned" apprentices with three years of experience than from hiring journeymen. Florentine apprentice Domenico, mentioned above, is a case in point. He left his master during the third year of his contract at 15 years of age, two years before it was due to finish. Witnesses testified that in the remaining two years of his contract Domenico would have woven one woollen cloth per month with profits for his master amounting

15. ASF, AL, 372, no. 352, 18 Jan. 1568.

16. ASF, AL, 374, no. 150, 28 Sept. 1574.

17. ASF, AL, 373, trial no. 236.

18. ASF, AL, 296, c. 28v, 31 Aug. 1574; ASF, b. 377, 20 May 1588; ASP, UL, 394, trial no. 20, c. 394r, October 1589; 84, c. $577 \mathrm{r}, 1594$.

19. ASP, UL, b. 46 , c. $193 \mathrm{r} ;$ b. 426 , cc. $125 \mathrm{v}-126 \mathrm{r}$; b. 394 , c. $192 \mathrm{r}$; b. 426 , c. $125 \mathrm{v}$; ASF, AL, b. 373, 31 March 1571. 
The price of an apprentice : contracts and trials in the woollen industry in $16^{\text {th }}$ century Italy

150 Andrea Caracausi

to 22 lire per cloth. Deducting the cost of food and wages his master would have earned 7 to 12 lire ${ }^{20}$ from his work. We might argue, here, that the amount demanded was to reimburse Domenico's master for time lost training his apprentice in the first year. However, we know that masters did not always teach apprentices in person but often entrusted training to journeymen. For this task, masters paid journeymen an additional 4 lire per cloth to compensate them for time lost teaching apprentices $^{21}$. If we deduct 4 lire (teaching cost per cloth for the first two years) from 7 to 12 lire (the master's net earnings from one 3-year-trained apprentice) we obtain a net gain of 3-8 lire per piece of cloth even in the first two years of apprenticeship.

In late-sixteenth-century Florence, 3-8 lire were about from 30 to $80 \%$ of a yearly apprentice weaver's monetary wage, which averaged at 10 lire a year, as the analysis of 78 weaving apprenticeship contracts shows ${ }^{22}$. In the first two to three years of keeping apprentices masters earned 3-8 lire monthly (about from 36 to 96 lire per year). In the fourth and fifth years, they earned 7-12 lire monthly or 84-144 lire per year, 8-14 times an apprentice's yearly wage (10 lire) after food and lodging costs have been deducted. So, although we can accept that masters lost money during the first year of training because their apprentices «were at a young age and cannot learn" easily ${ }^{23}$, it is also true that in all the years which followed they earned huge amounts from keeping apprentices.

Padua masters were equally clear on the issue of apprentice productivity. Master Alessandro Mussato from Mortise near Padua argued that agreed absences by his apprentice «to learn weaving" meant that he was unable to complete the high-quality woollen cloth he had contracted to deliver to merchants ${ }^{24}$. Merchants were adversely affected by apprentices' absences and asked judges for compensation, nominating experts to evaluate the ways in which apprentices « could make them

20. ASF, AL, 373, n. 236, 31 Mar. 1571, 3 and 5 April 1571.

21. ASF, AL, 296, c. 28v, 31 Aug. 1574, declarations of master weaver Cristiano Benedetto from Verona and Benedetto Silvestri from Carpi.

22. See Tab. 1 and Fig. 1.

23. ASF, AL, 375, trial no. 140, 27 Dec. 1576.

24. ASP, UL, 67, c. $219 \mathrm{v}, 13$ Nov. 1549. money" (lucrare, profit) $)^{25}$. And finally, in medium to large sized workshops, merchants claimed in the sources that if masters did not pay attention to their apprentices, the latter «did not work or did not learn to work" but «spent their time doing nothing and wages ran away ${ }^{26}$.

These considerations on age and aptitude lead us on to another factor which is usually claimed as determinant in wage levels: gender. Gender does not seem to have affected apprentice wage levels significantly. Young girls were not systematically paid lower wages, at least, for the same work, craft and time frame. If this did occur, it was not justified a priori by gender. In the Florentine weaving trade female apprentices were sometimes paid the same as boys and on occasions they were paid more even for contracts of the same length. This is illustrated by the case of a father who handed over his two children - a boy and a girl - to the same master. The former was paid a salary of 10 lire, the latter 15. As we might imagine, other factors played a decisive role here such as age, work skills and the market itself. Food costs for little girls were often lower and they were less prone to leaving early ${ }^{27}$.

\section{DRAWING UP CONTRACTS}

As we have seen, wage-levels varied according to the aptitude of (future) apprentices. These were observable, objective elements at the beginning of the contract (age, physical characteristics, etc.), but there were also other factors that were more difficult to estimate without some knowledge of the apprentice. For instance, how could ability, aptitude for learning, work and service be estimated if masters and apprentices knew little about each other in advance ${ }^{28}$ ? Guild-mandated minimum apprenticeship terms, entrance requirements (residence, family name or father's occupation) and completion certificates, it is argued, enabled adverse selection difficulties to be over-

25. ASP, UL, 82 , c. 540 r, 26 Oct. $1587 ; 87$, c. 6r, 1 Jun. 1620 ; b. 88, c. 315 r, 18 Sept. $1623 ; 88$, c. 339 r, 1636.

26. Caracausi 2011, p. 6.

27. Caracausi 2010.

28. Chang - Wang 1996, p. 505-506; Greenwald 1986, p. 325-326. See also Acemoglou - Pischke 1998 [Why do firms], p. 80; Gibbons - Kats 1991, p. 351-352. 
come and ensured better labour market functioning ${ }^{29}$. Such arguments are normally supported by evidence from statutory provisions or apprenticeship contracts which do not, however, reflect how masters really recruited apprentices or journeymen in practice.

Evidence from court cases shows that masters were able to evaluate apprentices prior to contracts and without the assistance of guilds or guild-like institutions. Apprentices also sometimes found employment with other masters before their contracts expired ${ }^{30}$. Real labour market recruitment was very different from that put forward by certain economic theories or even from what the actual content of apprenticeship or labour contracts would imply ${ }^{31}$. We therefore need to examine the way in which labour recruitment actually functioned and the mechanisms by which masters recruited apprentices more closely.

When masters and apprentices signed a contract they already knew something about each other. Future employees had actually usually already spent a probationary period with masters. It was only after such trial periods that employers and employees signed contracts and fixed wages. Masters regarded testing apprentices' abilities as a pre-requisite for contracts. Masters sometimes visited apprentices who had already spent a period of time with other masters to evaluate their abilities $^{32}$. Two master-weavers, Stefano di Francesco from Pratovecchio and Tommaso Ciabattino, assessed the work of Maddalena, an apprentice with another weaver-master, Antonio di Bastiano, and concluded that she was worth a yearly wage of 14 lire. They agreed on this sum after seeing how she worked and not because she had a guild completion certificate or had already spent some time (10 months) with another master ${ }^{33}$. It was seen as essential to see how an apprentice worked to assess his or her worth. Guild certificates and entrance requirements could not supply such information. After a trial period of 4-5 days, Florentine weaver Prospero di Bartolomeo from
Reggio refused to sign an agreement with young Gerolamo. After seeing Gerolamo at the loom, Prospero offered him a three-year contract but the apprentice refused ${ }^{34}$. Gerolamo later found another master with whom he signed a contract for 2 and half years at a yearly wage of 14 lire. Entrance requirements in particular were certainly included in the contract, but the latter was actually signed normally only after a probationary period ${ }^{35}$. In the knitting sector Giuseppe, son of Bernardino, said that the trial period for an apprentice without previous experience was sometimes as long as six months prior to a 3-year contract being signed ${ }^{36}$. Masters could also refuse to take apprentices after a probationary period and such apprentices had thus to transfer to another master for a new trial period $^{37}$. Unfortunately, there are no evidence on who paid food and lodging for such long periods. However, we can argue that advances on wages deserves to this goal.

Skills were evaluated by observing individual workers at the workplace. Contemporaries saw the best guarantees as consisting not in guild apprenticeship contracts, final proof or certification, but the knowledge that potential trainees and employees had worked - and worked well with other masters or merchants. Mortise weaver Giovanni Giacomo Mussatto would not return the money he had received for training his son to Sebastiano Betton's father because " he had taught Sebastiano well [...] because when Sebastiano left him, he had woven good cloth for other merchants, and in particular for ser Gerolamo del Bello and domino Bernardino dal Legname $"^{38}$ and such cases were not uncommon ${ }^{39}$.

As well as trial periods, other institutional mechanisms helped apprentices and journeymen to find employment and also provided employers with guarantees before contracts were drawn up. Firstly, apprentices and masters often took advantage of friendship or personal ties. When 15-year-old Gerolamo di Piero from Pianeti arrived in Florence, he first applied to Santo Antonio of
29. Epstein 1998, p. 692-693; Epstein 2008, p. 61.

30. ASP, UL, 56, c. 223v, 4 Mar. 1541 : ASF, AL, b. 372, trial no. 67.

31. See above, note 28 .

32. ASF, AL, 372, trial no. 67.

33. ASF, AL, 372, trial no 67, 4 Jun. 1567, 4 Jul. 1567, 30 Jul. 1567.
34. ASF, AL, 372, 21 Mar. 1568.

35. Caracausi 2010.

36. ASF, AL, 377, 24 May 1588.

37. ASP, UL, 87, c. 593v, 8 Jun. 1526

38. Caracausi 2014.

39. ASP, UL, 394 , fasc. 2 , c. 21 v, 5 Nov. 1546 ; b. 394 , c. 261 v, 23 Jul. 1571; 398, fasc. 9, c. 177r, 4 Jul. 1602. 
The price of an apprentice : contracts and trials in the woollen industry in $16^{\text {th }}$ century Italy

Santa Sofia as they came from the same village. Santo took him to a master who was looking for an apprentice $^{40}$. Employers exchanged information about apprentices' ability with outsiders too and often acted as intermediaries to help colleagues find good apprentices, journeymen or other masters as subcontractors. Weaver Jacopo di Tommasi, for example, knew apprentice Domenico and that he worked well because he «heard it from those who had worked with him ${ }^{41}$.

Masters and apprentices collected information about each other via colleagues, spent probationary periods together to find out more and only then signed employment contracts. The apprenticeship contracts often used as the basis for labour market research do not reveal such mechanisms but they emerge very vividly from legal cases (and other sources such as diaries).

\section{CONCLUSIONS}

This paper has highlighted a number of elements relating to apprentice wage-formation with the aim of stimulating further in-depth analysis of the topic. Combining apprentice contracts and court records and using both quantitative and qualitative evidence gives us a better understanding of pre-contract mechanisms and practices.

The first point to underline is the considerable variability in apprenticeship contract length. Several authors have argued that guilds imposed minimum apprenticeship time frames to compensate masters for time lost in teaching apprentices ${ }^{42}$. However, evidence from contracts and court cases shows that masters did not in fact take very long to train apprentices and time frames varied according to the specific occupation to be learnt and an apprentice's aptitude for it. This was not limited to the woollen industry but also occurred in the silk industry which is often taken as an example of a high quality industry that required longer apprenticeship periods. As other research for Italy and Europe has shown, in actual fact learning time frames varied and statutes and apprenticeship

40. ASP, AL, 372, n. 386, 16 Mar. 1568.

41. ASP, UL, b. 394, c. 2 lv, 5 Nov. 1546; ASF, AL, 373, trial no. 236, 31 Mar. 1571.

42. Epstein 1998, p. 691-692; Epstein 2008, p. 57-58, 60-61; Epstein - Prak 2008, p. 9. See also Wallis 2008. contracts confirm this ${ }^{43}$. Masters also accepted long periods of absence within apprenticeship contracts and recognized the skills of apprentices who left their workshops early to work as journeymen.

Apprentice recruitment is another issue which deserves more attention. Guild-mandated minimum apprenticeship terms, guild entrance requirements (residence, family name or father's occupation information) and completion certificates, it is argued, enabled adverse selection difficulties to be overcome and ensured better labour market functioning ${ }^{44}$. Such arguments are normally based on statutory provisions or apprenticeship contracts which do not reflect how masters actually recruited apprentices or journeymen in practice. Moreover, such theories do not explain how employers (and employees) resolved adverse selection problems in the absence of such institutional arrangements on the part of guilds even though they did in fact often do so. The evidence from these two case studies is that guild completion certificates and mandatory minimum apprenticeship contracts could not replace probationary periods or past knowledge from employers because skills were evaluated by observing individual workers at the workplace. Contemporaries saw the best guarantees as consisting not in guild apprenticeship contracts, final proof or certification, but in the knowledge that potential trainees and employees had worked - and worked well - with other masters or merchants. Masters and apprentices knew something about each other and collected this information from colleagues, spent probationary periods together to find out more and only then signed employment contracts. These practices, in particular trial periods, were common

43. Bellavitis 2006; Laudani 2006; Sciarrotta 2011, p. 150, 152-4; Kaplan 1993; De Munck 2011; Minns - Wallis 2012. For private contracts in the silk industry see Demo 2001, p. 171-174; Bellavitis 2006; Curatolo 1996; Laudani 2006; For statutes see Mocarelli 2008, p. 176. For silk weavers, apprenticeship varied from 4 to 7 years in velvet making (Catania 4, Verona and Brescia 5, Milan 6, Venice 5 - before 1678 - and 7 after 1678) and 5-6 years in damask making (Verona and Milan 5, Venice 5 - before 1678 - and 7 after 1678). See Zamboni, 1885, cap. 16; Demo 2001, p. 171, n. 51; Gli statuti della Università dei Tessitori di Seta, cap. xxx; Laudani 2006; Della Valentina 2003, p. 114. On the variation in the actual length of apprenticeship, see also Ben-Amos 1991, p. 166; Hamilton 1996; Minns - Wallis 2012, p. 558, 567; de Munck 2007, p. 59-68; Ogilvie 2014. 44. Epstein 1998, p. 692-693; Epstein 2008, p. 61. 
in other trades in Italy, Europe, and even nineteenth century North America ${ }^{45}$.

The last aspect to be considered is the balance between costs and benefits as well as work and service performed by apprentices, two elements which were common to many pre-modern industries $^{46}$. Long apprenticeship time frames cannot be explained simply by the fact that masters needed to be repaid for the costs of the first years of teaching. Masters earned huge profits on the work of their apprentices especially those with two or three years of experience and apprentices were seen as profitable for masters as they performed other jobs or worked with journeymen in return for low piece-rate wages even in these early years. These findings question the assumption that the training process has to be subdivided into separate stages in order « to explain discrepancies between the length of training programmes in various pre-industrial countries for roughly similar jobs ${ }^{47}$. In actual fact the evidence shows that masters had every reason to train apprentices as quickly as possible so that they would be more profitable, as cases like young apprentice Domenico clearly illustrate.

\section{Bibliography}

Acemoglu - Pischke 1998 = D. Acemoglu, J.-S. Pischke, Why Do Firms Train? Theory and Evidence, in Quarterly Journal of Economics 113, 1, 1998, p. 79-119.

Ammannati 2012 = F. Ammannati, "Se non piace loro l'arte, mutinla in una altra». I "lavoranti» dell'Arte della lana fiorentina tra XIV e XVI secolo, in Annali di Storia di Firenze, VII, 2012, p. 5-34.

Ammannati 2014 = F. Ammannati, Craft Guild Legislation and Woollen Production: The Florentine Arte Della Lana in the Fifteenth and Sixteenth Centuries, in B. De Munck, K. Davids (eds.), Innovation and Creativity in Late Medieval and Early Modern European Cities, Brookfield, 2014, p. 51-80.

Ammannati 2009 = F. Ammannati, Florentine Woolen Manufacture in the Sixteenth Century: Crisis and New Entrepreneurial Strategies, in Business and Economic History On-Line, 7, 2009, p. 1-9.

Ammannati 2008 = F. Ammannati, L'Arte della lana a Firenze nel cinquecento : crisi del settore e risposte degli operatori, in Storia Economica, 9, 1, 2008, p. 5-39.

Bellavitis $2006=$ A. Bellavitis, Apprentissages masculins, apprentissages féminins à Venise au XVIe siècle, in Histoire urbaine, 15, 1, 2006, p. 49-73.

Martini-Bellavitis 2014 = M. Martini, A. Bellavitis (eds.), Household Economies, Social Norms and Practices of Unpaid Market Work in Europe from the Sixteenth Century to the Present, in The History of the Family, 19, 3, 2014, p. 273282.

45. For probationary periods in other regions see Ben Amos 1988, p. 50-51 (England); Hamilton 1996, p. 498, 508 (North America); Kaplan 1993, p. 443 (France).

46. For apprentices obliged to work in a master's service: Demo 2001, p. 173; Della Valentina 2003, p. 55; Bellavitis 2006, p. 50-51; Laudani 2006, p. 14-15, 19; Groppi 1996, p. 139; De Munck 2011, p. 231 ; Ben-Amos 1988, p. 46-47.

47. Epstein and Prak 2008, p. 8. 
The price of an apprentice: contracts and trials in the woollen industry in $16^{\text {th }}$ century Italy

154 Andrea Caracausi

Chang - Wang 1996 = C. Chang, Y. Wang, Human Capital Investment Under Asymmetric Information: The Pigovian Conjecture Revisited, in Journal of Labor Economics, 14, 3, 1996, p. 505-519.

Curatolo 1996 = P. Curatolo, Struttura, crisi e trasformazione di un sistema produttivo urbano: le corporazioni auroseriche milanesi: (1570-1720), Milan, 1996.

De Munck 2011 = B. De Munck, Gilding Golden Ages: Perspectives from Early Modern Antwerp on the Guild Debate, c. 1450 - c. 1650, in European Review of Economic History, 15, 2, August 1, 201 1, p. 221-53.

De Munck et al. 2007 = B. De Munck, S. L. Kaplan and H. Soly, Learning on the Shop Floor: Historical Perspectives on Apprenticeship, New York-Oxford, 2007.

De Munck 2007 = B. De Munck, Technologies of Learning: Apprenticeship in Antwerp Guilds from the $15^{\text {th }}$ Century to the End of the Ancien Régime, Turnhout, 2007.

Della Valentina $2003=$ M. Della Valentina, Operai, mezzadi, mercanti. Tessitori e industria della seta a Venezia tra '600 e'700, Padua, 2003.

Demo 2001 = E. Demo, L'anima della città : l'industria tessile a Verona e Vicenza (1400-1550), Milan, 2001.

Epstein 2008 = S. R. Epstein, Craft Guilds in the Pre-Modern Economy: A Discussion, in The Economic History Review, 61, 1, February 1, 2008, p. 155-174.

Epstein 1998 = S. R. Epstein, Craft Guilds, Apprenticeship, and Technological Change in Preindustrial Europe, in The Journal of Economic History, 58, 03, 1998, p. 684-713.

Epstein 2008 = S. R. Epstein, Craft Guilds, Apprenticeship, and Technological Change in Preindustrial Europe, in S. R. Epstein, M. Prak (eds.), Guilds, Innovation, and the European Economy, 1400-1800, Cambridge, 2008.

Epstein - Prak 2008 = S. R. Epstein, M. Prak. Introduction: Guilds, Innovation, and the European Economy, 1400-1800, in S. R. Epstein, M. Prak (eds.), Guilds, Innovation, and the European Economy, 1400-1800, Cambridge, 2008, p. 1-24.

Franceschi 1993 = F. Franceschi, Oltre il "Tumult» : $i$ lavoratori fiorentini dell'Arte della Lana fra Tre e Quattrocento, Florence, 1993.

Gibbons - Katz 1991 = R. Gibbons, L. F. Katz, Layoffs and Lemons, in Journal of Labor Economics, 9, 4, 1991, p. 351-380.

Greenwald $1986=$ B. C. Greenwald, Adverse Selection in the Labour Market, in The Review of Economic Studies, 53, 3 , 1986, p. 325-47.

Groppi 1996 = A. Groppi, Lavoro e proprietà delle donne in età moderna, in A. Groppi (ed.), Il lavoro delle donne, Roma-Bari, 1996, p. 119-63.

Gustafsson 1987 = B. Gustafsson, The Rise and Economic Behaviour of Medieval Craft Guilds an Economic-Theoretical Interpretation, in Scandinavian Economic History Review, 35, 1, 1987, p. 1-40.

Hamilton 1996 = G. Hamilton, The Market for Montreal Apprentices: Contract Length and Information, in Explorations in Economic History, 33, 4, 1996, p. 496-523.

Kaplan 1993 = S. L. Kaplan, L'apprentissage au XVIII siècle: le cas de Paris, in Revue d'Histoire Moderne et Contemporaine, 40, 3, 1993, p. 436-479.
Laudani 2006 = S. Laudani, Apprenties ou jeunes salariées?, in Histoire urbaine, 15, 1, March 1, 2006, p. 13-25.

Leunig et al. $2011=\mathrm{T}$. Leunig, C. Minns, P. Wallis, Networks in the Premodern Economy: The Market for London Apprenticeships, 1600-1749, in The Journal of Economic History, 71, 02, 2011 , p. 413-443.

Maitte $2001=\mathrm{C}$. Maitte, La trame incertaine: le monde textile de Prato, XVIII $-X I X^{e}$ siècles, Lille, 2001.

Malanima 1982 = P. Malanima, La decadenza di un'economia cittadina: l'industria di Firenze nei secoli XVI-XVIII, Bologna, 1982.

Marcello 1993 = L. Marcello, Andare a bottega. Adolescenza $e$ apprendistato nelle arti (sec. XVI-XVII), in O. Niccoli (ed.), Infanzie. Funzioni di un gruppo Liminale dal mondo classico all'età moderna, Florence, 1993, p. 231-51.

Minns - Wallis 2012 = C. Minns, P. Wallis, Rules and Reality: Quantifying the Practice of Apprenticeship in Early Modern England, in The Economic History Review, 65, 2, 2012, p. 556-579.

Minns - Wallis $2013=$ C. Minns, P. Wallis, The Price of Human Capital in a Pre-Industrial Economy: Premiums and Apprenticeship Contracts in $18^{\text {th }}$ Century England, in Explorations in Economic History, 50, 3, 2013, p. 335350.

Mocarelli 2008 = L. Mocarelli, Guilds Reappraised: Italy in the Early Modern Period, in International Review of Social History, 53, Supp. S16, 2008, p. 159-178.

Ogilvie 2004 = S. Ogilvie, Guilds, Efficiency, and Social Capital: Evidence from German Proto-Industry, in The Economic History Review, 57, 2, May 1, 2004, p. 286333. doi : 10.1111/j.1468-0289.2004.00279.x.

Ogilvie 2008 = S. Ogilvie, Rehabilitating the Guilds : A Reply, in The Economic History Review 61, 1, February 1, 2008, p. 175-82. doi: 10.1111/j.1468-0289.2007.00417.x.

Ogilvie 2014 = S. Ogilvie, The Economics of Guilds, in Journal of Economic Perspectives, 28, 4, November 2014, p. 169-92. doi : 10.1257/jep.28.4.169.

Ogilvie 2007 = S. Ogilvie, "Whatever Is, Is Right» ? Economic Institutions in Pre-Industrial Europe, in The Economic History Review, 60, 4, November 1, 2007, p. 649-84. doi : 10.1111/j.1468-0289.2007.00408.x.

Panciera 1996 = W. Panciera, L'arte matrice : lanifici della Repubblica di Venezia nei secoli 17 e 18, Treviso, 1996.

Pfister 2008 = U. Pfister, Craft Guilds, the Theory of the Firm, and Early Modern Proto-Industry in S. R. Epstein, M. Prak (eds.), Guilds, Innovation and the European Economy, 1400-1800, Cambridge, 2008, p. 25-51.

Sciarrotta 2011 = S. Sciarrotta, Artigiani. La rete dei mestieri e l'organizzazione del lavoro a Salerno, Salerno, 2011.

Wallis $2008=$ P. Wallis, Apprenticeship and Training in Premodern England, in The Journal of Economic History, 68, 3, 2008, p. 832-861.

Van Zanden 2009 = J.-L. Van Zanden, The Long Road to the Industrial Revolution: The European Economy in a Global Perspective, 1000-1800, Leiden-Boston, 2009.

Zamboni 1965 = P. Zamboni, Monografia del setificio veronese, Verona, 1885. 